\title{
KEPRIBADIAN TOKOH DALAM NOVEL MENCARI PEREMPUAN YANG HILANG (KAJIAN PSIKOANALISIS CARL GUSTAV JUNG)
}

\author{
Tri Septiarini [1], Renni Handayani Sembiring [2]
}

\author{
[1] 39rini@gmail.com, [2] rennikembaren@gmail.com \\ Universitas Negeri Jakarta \\ Jakarta, Indonesia
}

\begin{abstract}
Abstrak: Dewasa ini, psikoanalisis yang lazim digunakan sebagai pendekatan penelitian adalah aspek kaidah-kaidah psikologi yang terdapat dalam karya sastra khususnya karakter tokoh-tokoh utama. Novel Mencari Perempuan yang Hilang karya DR. Imad Zaki, alih bahasa oleh Dr. Zuriyati menceritakan kisah pilu seorang wanita yang menghilang dari peradaban karena berat untuk menanggung beban kejahatan ayahnya yang merugikan orang banyak. Penelitian ini bertujuan untuk: (a) mengetahui bagaimana deskripsi tokoh-tokoh utama dalam novel yaitu Dokter Ahlam, Dokter Sholeh dan Abdul Ghani Zahabi; (b) mengetahui bagaimana tingkat kepribadian pada masing-masing tokoh utama; dan (c) mengetahui tipe kepribadian tokoh-tokoh utama dalam novel. Penelitian ini menerapkan analisis isi dengan pendekatan kualitatif. Dokter Sholeh dan dokter Ahlam mempunyai karakter yang positif. Abdul Ghani Zahabi mempunyai karakter kejam. Dokter Sholeh cenderung memiliki tingkatan kepribadian kesadaran dan ketidaksadaran kolektif (persona). Dokter Ahlam cenderung memiliki tingkatan kepribadian kesadaran dan ketidaksadaran kolektif (animus). Dan Abdul Ghani Zahabi cenderung memiliki tingkatan kepribadian ketidaksadaran personal dan ketidaksadaran kolektif (persona, bayangan, dan anima). Dokter Sholeh cenderung termasuk kedalam tipe kepribadian ekstroversi (pemikir, perasa dan intuitif). Dokter Ahlam cenderung termasuk pada tipe kepribadian introversi (perasa dan intuitif). Dan Abdul Ghani Zahabi cenderung termasuk kedalam tipe kepribadian ekstroversi (pemikir dan perasa) dan introversi (pemikir dan intuitif).
\end{abstract}

Kata kunci: Novel Mencari Perempuan yang Hilang, Psikoanalisis Carl Gustav Jung, Kepribadian Tokoh Utama

\section{PENDAHULUAN}

Manusia adalah makhluk yang unik di mana setiap individu berbeda dengan yang lainnya. Hal ini terlihat dari watak, tempramen, pengalaman, pandangan dan perasaan individu yang berbeda. Pertemuan antarmanusia yang satu dengan manusia lainnya tidak jarang menimbulkan konflik, baik konflik antarindividu, kelompok maupun anggota kelompok. Karena sangat kompleks, manusia juga sering mengalami konflik yang dialami oleh dirinya sendiri atau konflik batin. Dengan kata lain, manusia selalu dihadapkan dengan persoalan-persoalan kehidupan.
Untuk menghadapi persoalan tersebut, manusia tidak dapat terlepas dari jiwa manusia itu sendiri. Di era post-modern ini, banyak sekali terlihat penyimpangan perilaku manusia yang disebabkan oleh konflik seperti meningkatnya angka kematian baik bunuh diri ataupun pembunuhan yang disebabkan karena cemburu berlebihan, perselingkuhan, kesalahpahaman, kemiskinan, stress, dan lemahnya iman.

Novel Mencari Perempuan yang Hilang karya DR. Imad Zaki, alih bahasa oleh Dr. Zuriyati menceritakan kisah pilu seorang wanita yang menghilang dari peradaban 
karena berat untuk menanggung beban kejahatan ayahnya yang merugikan orang banyak. Kisah seorang wanita yang menghilang dari peradaban karena tidak jadi menikah dengan kekasih pujaan hati karena sikap ayahnya yang arogan, ambisius dan serakah. Tidak hanya itu, novel ini juga mengisahkan seorang anak kandung yang tidak dididik dengan benar dan penuh kasih sayang oleh orang tuanya. Konflik yang dialami dalam tokoh-tokoh utama adalah konflik batin, konflik antarindividu, dan kelompok. Konfliknya terjadi karena disebabkan oleh kejahatan, kecurangan, ketidakjujuran, kesalahpamahan, dan keserakahan.

Psikoanalisis menunjukkan suatu penelitian terhadap proses psikis. Di mana membahas mengenai kepribadian yang mencakup struktur, dinamika dan perkembangan kepribadian. Dengan menggunakan psikoanalisis, pembaca dapat menjelaskan proses kreatif suatu karya sastra. Hal itu juga berguna karena jika dipakai dengan tepat dapat membantu pembaca melihat keretakan, ketidakteraturan, perubahan, dan distorsi yang sangat penting dalam suatu karya sastra. Misal, perubahan karakter tokoh, perubahan alur yang digunakan, koreksi naskah, dan seterusnya hingga jalan cerita tidak dapat ditebak dengan mudah oleh pembaca.

Dewasa ini, psikoanalisis yang lazim digunakan sebagai pendekatan penelitian adalah yang diarahkan pada aspek kaidahkaidah psikologi yang terdapat dalam karya sastra khususnya karakter tokoh-tokoh utama. Walaupun terdapat tiga aspek lainnya yang termasuk dalam pendekatan penelitian berbasis psikoanalisis yaitu aspek psikologi pengarang, proses penciptaan sastra, dan pengaruhnya terhadap jiwa pembaca. Berdasarkan kelaziman tersebut, peneliti juga menggunakan aspek kaidah-kaidah psikologi yang terdapat dalam karya sastra dengan mengamati karakter tokoh-tokoh utama dan menggambarkannya dengan menganalisis setiap tokoh utama yang terlibat.

Berdasarkan penelitian yang dilakukan oleh Pilda Nugarah Firdaus (2016) tentang "Gangguan Kepribadian Tokoh dalam Novel Mencari Perempuan yang Hilang karya DR. Imad Zaki, alih bahasa oleh Dr. Zuriyati: Kajian Psikologi Sastra" menemukan bahwa terdapat
4 macam gangguan yang terjadi dalam beberapa tokoh, diantaranya adalah gangguan kepribadian narsistik, ambang, histrionik, dan obsesif kompulsif. Namun, masing-masing gangguan kepribadian toko dalam novel memiliki bentuk gangguan kepribadian yang bervariatif.

Berbeda dengan penelitian yang sebelumnya, fokus penelitian ini adalah aspek kepribadian tokoh utama Novel Mencari Perempuan yang Hilang karya DR. Imad Zaki, alih bahasa oleh Dr. Zuriyati. Penelitian ini bertujuan untuk mendapatkan pemahaman yang mendalam bagaimana Novel Mencari Perempuan yang Hilang karya DR. Imad Zaki, alih bahasa oleh Dr. Zuriyati menggunakan teori kepribadian Carl Gustav Jung.

\section{KAJIAN TEORI}

Menurut Jaenudin (2012, h. 116-118), kepribadian adalah: (a) kesatuan yang kompleks, yang terdiri atas psikis seperti intelegensi, sifat, sikap, minat, cita-cita dan sebagainya, serta aspek fisik seperti bentuk tubuh, kesehatan jasmani, dan sebagainya; (b) kesatuan dari kedua aspek tersebut berinteraksi dengan lingkungannya yang mengalami perubahan secara terus menerus dan terwujudlah pola tingkah laku yang khas atau unik; (c) kepribadian bersifat dinamis, artinya selalu mengalami perubahan, tetapi dalam perubahan tersebut terdapat pola-pola yang bersifat tetap; dan (d) kepribadian terwujud berkenaan dengan tujuan-tujuan yang ingin dicapai. Dapat disimpulkan bahwa, kepribadian terdiri dari dua bentuk yaitu fisik dan psikis yang bersifat dinamis demi tercapainya tujuan-tujuan yang ingin dicapai.

Berdasarkan pengertian kepribadian di atas, Schultz \& Schultz (2005) merumuskan tujuh faktor yang dapat mempengaruhi perkembangan kepribadian, yaitu sebagai berikut: (1) Faktor genetik atau hereditas, kepribadian sepenuhnya ditentukan oleh bawaan; (2) Faktor lingkungan, perbedaan lingkungan dan sosial akan berpengaruh terhadap perbedaan kepribadian antara individu satu dengan lainnya; (3) Faktor belajar, setiap fase dalam kepribadian yang diwariskan dapat dimodifikasi, dikacaukan, dicegah, ditumbuh-suburkan melalui proses belajar; (4) Faktor pengasuhan orang tua, pola pengasuhan yang positif memiliki efek positif terhadap anak, sementara pola 
pengasuhan yang negatif akan memberikan pengaruh yang merusak; (5) Faktor perkembangan, perasaan, rencana, dan tujuan berubah sepanjang kehidupan sebagai hasil dari bermacam-macam pengaruh. Sementara naskah hidup berdampak pada pembentukan diri (self), pencapaian identitas, dan menemukan penyatuan tujuan dalam hidup; (6) Faktor kesadaran, hampir semua teori kepribadian, secara implisit dan eksplisit, menjelaskan proses kesadaran; dan (7) Faktor ketidaksadaran, Sigmund Freud memperkenalkan tentang dunia tidak sadar; gudang kesuraman dari ketakutan paling gelap, konflik-konflik, kekuatan yang berpengaruh pada pemikiran sadar.

Menurut Jung, kepribadian manusia diawali dengan kesadarannya mengenai dua sisi dirinya. Jung menyadari ada sisi dominan, yang tampak pada suatu waktu pada dirinya semasa hidup. Sisi-sisi tersebut menjadikan Jung dapat bersikap objektif dan subjektif. Hal ini dikarenakan setiap manusia tidak memiliki kemutlakan kepribadian, sehingga seseorang dapat saja menjadi introvert maupun ekstrovert. Jung mengungkapkan bahwa manusia tidak hanya memiliki ketidaksadaran pribadi, tetapi juga memiliki ketidaksadaran kolektif. Adapun ketidaksadaran kolektif itu berisi gambaran-gambaran primitif, antara lain bayangan, pesona, anima, dan animus.

\section{Tingkatan Kepribadian menurut Carl Gustav Jung}

Tingkatan kepribadian menurut Jung terkait dengan perihal kesadaran dan ketidaksadaran di dalam kepribadian yang dicetuskan Jung. Menurut Matthew (2013, h. 129-137), tingkatan kepribadian Jung yakni terdiri atas:

a. Kesadaran, yaitu hal yang dapat dirasakan oleh ego (pusat kesadaran utuh). Kesadaran dalam psikoanalisis Jung hanya berperan kecil, karena menurut Jung kesadaran merupakan bagian kecil saja dari kepribadian.

b. Ketidaksadaran personal, yaitu pengalaman yang terlupakan. Ketidaksadaran ini diperoleh oleh seseorang selama hidupnya.

c. Ketidaksadaran kolektif, yaitu ketidaksadaran yang mengakar dari masa lalu leluhur. Ketidaksadaran ini diperoleh dari generasi terdahulu. Ketidaksadaran ini berkaitan dengan pikiran, emosi, dan tindakan seseorang. Selain itu, ketidaksadaran ini juga berhubungan dengan kepercyaan, mitos dan legenda. Menurut Feist dan J. Fiest (2006, h. 103109), ketidaksadaran kolektif terdiri atas:

- Persona, yaitu sisi kepribadian yang ditunjukkan seseorang kepada dunia atau lingkungannya karena tuntutan sosial.

- Bayangan, yaitu represi yang menampilkan kualitas-kualitas yang tidak akui keberadannya dan berusaha disembunyikan dari diri sendiri dan orang lain.

- Anima, yaitu sisi feminin pada pria yang dapat berupa penjiwaan seperti wanita.

- Animus, yaitu sisi maskulin pada wanita yang berkaitan dengan proses berpikir dan bernalar. Animus mempengaruhi proses berpikir seseorang wanita yang sebenarnya tidak dimiliki seorang wanita.

Menurut Howard \& Miriam (2008, h. 128-133), adapun ketidaksadaran personal berhubungan dengan ketidaksadaran yang telah diterima sejak seseorang masih kecil. Ketidaksadaran kolektif berkaitan dengan ketidaksadaran dari generasi sebelumnya termasuk sisi feminin dan maskulin. Dari keterangan tentang tingkatan kepribadian Jung, dapat disimpulkan bahwa psikoanalisis Jung dalam ranah tingkatan kepribadian /berkaitan dengan kesadaran dan ketidaksadaran.

\section{Tipe Kepribadian menurut Carl Gustav Jung}

Kepribadian Jung berkaitan dengan sikap jiwa. Menurut Matthew (2013, h. 138), sikap jiwa adalah energi psikis umum yang menjelma dalam bentuk orientasi manusia terhadap dunianya, yaitu tipe ekstrovert (dipengaruhi dunia objektif), tipe introvert (dipengaruhi oleh dunia subjektif). Jadi bisa disimpulkan bahwa orientasi tipe ekstraversi adalah orientasi keterbukaan (ke luar), sedangkan orientasi tipe introversi adalah ketertutupan (ke dalam). Seseorang dapat memiliki salah satu tipe kepribadian ini, namun dapat pula memiliki campuran dari dua tipe tersebut. 
Tipe ekstraversi dan introversi adalah sikap jiwa. Sikap jiwa ini memiliki fungsifungsi jiwa tersendiri. Jung menjelaskan bahwa tipe ekstraversi dan introversi memiliki empat fungsi yang terpisah yaitu dua fungsi rasional (pikiran dan perasaan), dan dua fungsi irasional (pendrian dan intuisi). Melalui penejelasan tentang fungsi jiwa tersebut dapat diketahui bahwa berpikir dan merasakan merupakan kegiatan yang rasional, sedangkan kegiatan melalui pendrian dan intuisi berkaitan dengan subjektivitas yang dimiliki seseorang. Berikut adalah penjelasan mengenai dua fungsi rasional dan dua fungsi irasional Menurut Feist dan J. Fiest (2006, h. 103-109),

- Pikiran yaitu aktivitas berpikir yang mengacu pada aktivitas intelektual logika yang memproduksi serangkaian ide;

- Perasaan yaitu digunakan untuk mendeskripsikan proses evaluasi sebuah ide atau kejadian;

- Pendria yaitu aktivitas yang menerima rangsangan fisik dan mengubahnya ke dalam bentuk kesadaran perseptual; dan

- Intuisi yaitu aktivitas yang meliputi persepsi yang berada jauh di luar sistem kesadaran.

Dengan mengkombinasikan dua sikap dan empat fungsi di atas, Menurut Feist dan J. Fiest (2006, h. 103-109), Jung menjelaskan 8 tipe kepribadian yang berbeda, yaitu:

a. Pimikir-Intraversi, seseorang dengan sikap yang intraversi dan fungsi pemikir yang dominan biasanya tidak memiliki emosi dan tidak ramah serta kurang bisa bergaul. Hal ini terjadi karena mereka memiliki kecenderungan untuk memperhatikan nilai abstrak dibandingkan orang-orang dan lingkungan sekitarnya. Mereka lebih mengejar dan memperhatikan pemikirannya tanpa memperdulikan apakah ide mereke diterima oleh orang lain atau tidak. Mereka biasanya keras kepala, sombong dan berpendirian.

b. Pemikir-Ekstraversi, seseorang dengan sikap ekstraversi dan fungsi pemikir yang dominan memiliki kecenderungan untuk muncul seorang diri, dingin dan sombong. Seperti pada tipe pertama, mereka juga me-repress fungsi perasa. Kenyataan yang objektif merupakan aturan untuk mereka dan mereka menginginkan orang lain juga berpikir hal yang sama.

c. Perasa-Intraversi, seseorang dengan intraversi-perasa berpengaruh alam emosi yang kuat, namun mereka enggan untuk terbuka. Mereka mengekspresikan perasaannya hanya dalam bentuk seni. Mereka mungkin menampilkan keselarasan di dalam dirinya dan selfefficacy, namun perasaan mereka dapat meledak dengan tiba-tiba.

d. Perasa-Ekstroversi, seseorang dengan sikap ekstraversi dan fungsi perasa yang dominan perasaan dapat berubah sebanyak situasi yang berubah. Mereka cenderung untuk emosional dan moody tapi terkadang sikap sosialnya dapat muncul.

e. Pendria-Intraversi, orang ini cenderung tenggelam dalam sensasi fisik mereka dan untuk mencari hal yang tidak menarik dari dunia sebagai perbandingan. Biasanya mereka adalah orang-orang yang tenang, kalem, self-controlled, tapi mereka juga membosankan dan kurang bisa berkomunikasi.

f. Pendria-Ekstroversi, seseorang dengan tipe pendria-ekstroversi biasanya realistik, praktis, dan pekerja keras. Mereka menikmati apa yang dapat mereka indrai dari dunia ini, menikmati cinta dan mencari kegairahan. Mereka mudah dipengaruhi oleh peraturan dan mudah ketagihan pada berbagai hal.

g. Intuitif- Intraversi, seseorang dengan sikap intraversi dan fungsi intuitif yang dominan adalah mereka terisolasi dalam gambaran-gambaran primitf yang artinya tidak selalu mereka ketahui namun selalu muncul dalam pikiran mereka. Mereka memiliki kesulitan dalam berkomunikasi dengan orang lain, tidak praktis namun memiliki intuisi yang sangat tajam dibandingkan orang lain.

h. Intuitif-Ekstroversi, seseorang dengan sikap ekstraversi dan fungsi intuitif yang dominan adalah orang-orang yang selalu mencari sesuatu yang baru. Mereka sangat baik dalam mempromosikan hal-hal yang baru. Namun tidak dapat bertahan pada satu ide pekerjaan maupun lingkungan karena sesuatu yang baru merupakan tujuan hidup mereka. 
Berdasarkan penjelasan mengenai tipe kepribadian Jung, maka ditarik kesimpulan bahwa tipe kepribadian Jung terdiri atas ekstraversi dan introversi. Dimana, masingmasing berkisar pada pikiran, perasaan, pendira, dan intuisi. Pada seseorang dimungkinkan memiliki kepribadian baik ekstraversi dan introversi. Hal ini dikarenakan jiwa seseorang yang dapat rapuh pada suatu saat, dan juga euphoria pada suatu saat lainnya.

\section{METODOLOGI PENELITIAN}

Penelitian ini menggunakan analisis isi dengan menggunakan pendekatan kualitatif. Metode analisis isi kualitatif digunakan untuk memahami pesan simbolik dari wacana atau teks. Analisis dilakukan terhadap tiga tokoh utama yaitu Dokter Sholeh, Dokter Ahlam dan Abdul Ghani Zahabi. Untuk menganalisis ketiga tokoh ini akan digunakan teori Carl Gustav Jung yaitu tipe kepribadian dan tingkatan kepribadian. Teori tersebut digunakan untuk mendeskripsikan struktur kepribadian yang ada dalam tiap-tiap tokoh untuk melihat bagaimana mereka merepresi dan mempresentasikan tipe dan tingkatan kepribadian yang mereka gunakan. Instrumen data yang digunakan dalam penelitian ini adalah peneliti sendiri dengan dibantu tabeltabel kerja berdasarkan subfokus penelitian yaitu: (a) Deskripsi tokoh-tokoh utama dalam novel yaitu Dokter Ahlam, Dokter Sholeh dan Abdul Ghani Zahabi; (b) Tingkat kepribadian pada masing-masing tokoh utama yaitu Dokter Ahlam, Dokter Sholeh dan Abdul Ghani Zahabi; dan (c) Tipe kepribadian tokoh-tokoh utama dalam novel yaitu Dokter Ahlam, Dokter Sholeh dan Abdul Ghani Zahabi.

\section{PEMBAHASAN TEMUAN PENELITIAN}

Pembahasan temuan penelitian ini disesuaikan dengan fokus dan subfokus penelitian, lalu diinterpretasi atau diverifikasi temuan yang didapat dengan menghubungkannya dengan teori yang ada. Pembahasan temuan penelitian berdasarkan fokus penelitian yaitu aspek kepribadian tokoh utama Novel Mencari Perempuan yang Hilang karya DR. Imad Zaki, alih bahasa oleh Dr. Zuriyati.

\section{Deskripsi Tokoh-tokoh Utama \\ 1. Dokter Sholeh al-Hakim}

Pengenalan tokoh Dokter Sholeh alHakim secara tersurat pada awal kisah dalam novel ini. Pengenalannya pun secara langsung. Hal ini terlihat dari tokoh "aku" yang diceritakan dalam novel adalah tokoh Dokter Sholeh al-Hakim itu sendiri. Pengenalan yang diawali dengan kisah tokoh "aku" atau Dokter Sholeh yang putus asa karena dia sangat merindukan sosok Dokter Ahlam.

"Dari lubuk hatiku yang paling dalam terpancar kembali suatu harapan bagaikan pancaran parfum dari leher semprotannya. Harapan yang memupus keputusasaan yang kuderita sekian lama. $Y a$, sekian lama aku lelah, letih dan berlari untuk mengejarnya.Kerinduan mulai membara, melambaikan dan mengibaskan sayap keceriaan untuk membawaku terbang ke angkasa." (hlm,7).

Dokter Sholeh adalah seorang dokter dan teman yang sangat amanah. Hal ini terlihat dari cerita Dokter Ahlam yang sangat rahasia, tapi dia berani dan percaya untuk menceritakannya.

"Percayalah! Cerita ini akan kujadikan rahasia yang sangat berharga. Akan kusimpan dan akan kukubur dalam hatiku sehingga tak seorangpun bisa membacanya." (hlm, 84).

Dokter Sholeh mempunyai jiwa peduli yang sangat tinggi terhadap permasalahan kehidupan masyarakat. Hal ini terlihat dari cara dia berjuang dalam menyibakkan misteri bayi malang dan kesiapan dia dengan semua resiko buruk yang akan menimpanya. Jiwa pedulinya terlihat dari ucapan tokoh lain yaitu Ustadz Said.

".......Aku simpati terhadap
perjuanganmu dalam menyibakkan
misteri bayi malang itu. Baik, besok aku
muat beritanya di lembaran depan
koranku."(hlm, 59).
Deskripsi Dokter Sholeh juga terlihat dari pembicaraannya dengan Dokter Ahlam yang mengatakan seperti apa Dokter Sholeh yang sebenarnya.

"..... Aku hanya pemuda biasa dan hidup bersahaja. Sama seperti pemuda lain, aku juga mempunyai banyak keinginan dan mimpi-mimpi, punya derita dan nestapa. Kalau soal rajin dan ulet, kuakui mungkin lebih dari mereka. Keteguhanku memegang nilai-nilai, moral dan etika 
juga boleh dikatakan sedikit lebih kuat dari mereka. Hanin pernah menyebutku pemuda teladan, pemuda luar biasa. Tapi aku merasa tidak ada yang luar biasa dariku. Aku bukan orang penting seperti yang dikatakan Hanin." (hlm, 76).

\section{Dokter Ahlam Zahabi}

Pengenalan tokoh Dokter Ahlam Zahabi secara tersirat pada awal kisah dalam novel ini. Pengenalannya pun tidak secara langsung, melainkan melalui ucapan tokoh lain yaitu Dokter Sholeh.

"Jantungku berdegup kencang begitu melihat wajahnya. Aku seakan baru saja terlahir kembali setelah sekian lama mati. Aku terpukau bagaikan bayi yang menatap keajaiban dunia. Siapa dia? Ahlam? Auranya menembus mataku, langkahnya menusuk telingaku. Oh .... Ahlam kembali? Kembali ke kota yang sudah lama dia tinggalkan? Ya, tentu dia akan berjumpa dan bergurau lagi dengan orang-orang yang bangga akan prestasinya. Kehadirannya bagaikan fajar shubuh menyibak kegelapan malam atau bagaikan matahari mencairkan gumpalan mendung yang hitam." (hIm, 7).

Dokter Ahlam adalah dokter yang sangat penyayang dan tidak tegaan. Hal ini terlihat dari ucapan Dokter Sholeh mengenai respon Dokter Ahlam karena misteri bayi yang terjadi di RS tempat mereka bekerja.

“..... Lebih-lebih Ahlam. Dia seakan terpukul berat dengan peristiwa ini. Dia tidak sanggup membendung air matanya. Dia menangis." (hlm, 19).

"Ahlam menyambut bayi itu dari tangan polisi, lalu mendekapnya dengan kasih sayang. Dia bersenandung memberikan rasa nyaman untuk bayi itu. Bayi itupun terdiam, seakan merasakan kelembutan Ahlam...." (hlm, 19).

Namun, hal itu berbanding terbalik dengan masa kecil Dokter Ahlam yang sangat kurang mendapatkan kasih sayang dari orangtuanya.

"Jalan hidup kita jauh berbeda, Dokter Sholeh! Bagaikan malam dan siang. Kehadiranku di muka bumi ini sudah ditunggu oleh sendok emas. Itulah katakata yang sering diungkapkan ayahku. Begitu mataku terbuka, aku ditenggelamkan ke dalam kemewahan yang berlimpah ruah. ...... Semua aku punya kecuali kasih sayang yang hakiki." (hlm, 78-79).

"Ya, kasih sayang. Aku kehilangan kasih sayang sejak kecil...." (hlm, 79).

Dokter Ahlam terkenal dengan sifatnya yang baik hati, gigih dan tangguh.

"Dia dokter yang baik hati, gigih dan tangguh." (hlm, 107).

Dokter Ahlam adalah orang yang sangat pintar menyembunyikan sesuatu, seperti hobinya yaitu melukis bahkan permasalahan terbesar dalam hidupnya.

"Aku pelukis ulung....." (hlm, 75).

"Sejak kejadian buruk itu, bertahuntahun lamanya sampai sekarang aku menyimpan rahasia itu dalam dadaku. Sekial lama rahasia itu aku bawa ke mana aku pergi dengan hati yang tersiksa. Sejak itu pula rasa hormat dan kepercayaanku kepada ayah hilang dan punah sama sekali. " (hlm, 138).

Dokter Ahlam juga seorang anak yang sangat menjunjung kebenaran yang sangat kuat. Hal ini terbukti dengan kesaksiannya di pengadilan untuk mengungkapkan kesalahan ayahnya dan kebenaran yang sesungguhnya.

"Dengan menyebut nama Allah Yang Maha Besar saya bersumpah akan mengatakan kebenaran sepahit apa pun. Akan saya katakan meski manusia menuduh saya anak durhaka, pengkhianat, bahkan gila. " (hlm, 350).

\section{Abdul Ghani Zahabi}

Pengenalan tokoh Abdul Ghani Zahabi secara tersirat pada awal kisah dalam novel ini. Pengenalannya pun tidak secara langsung, melainkan melalui ucapan tokoh lain yaitu Dokter Hanin.

"Dokter Ahlam adalah anak seorang miliader. Namanya Abdul Ghani Zahabi. Dia memiliki segudang saham, deposito, asuransi dan lain-lain di bank. Punya harta, pangkat dan kekuasaan, seorang hakim tanpalembaga, seorang raja tanpa mahkota. Dia terkenal sebagai penguasa." Hanin menatap reaksi wajahku sambil bertanya, "Apa kau pernah mendengar pengusaha dan penguasa emas? Dialah ayah Ahlam." (hlm, 35).

Karakter Abdul Ghani terlihat secara langsung dari pengakuannya tentang kasus kriminal yang telah dia lakukan di pengadilan. 
"Tuan Hakim! Saya mengakui semua apa yang dikatakan oleh anak saya, Ahlam. Dia benar.. saya penipu, pencuri, dan pembunuh. Saya mengaku telah mempermainkan undang-undang yang berlaku....." (hlm, 360).

Karakter Abdul Ghani yang licik semakin diperkuat dengan tingkah lakunya saat menjebak Dokter Sholeh saat berkunjung ke kantornya demi Ahlam. Selain sebagai pengusaha sukses, ayah adalah seorang yang culas dan tamak. Dia menghalalkan berbagai macam cara demi meraih keuntungan. Salah satu hal yang diangkat dalam novel ini adalah sang ayah menjual makanan bayi dan obatobatan yang hampir kadaluarsa bahkan yang kadaluarsa. Hal ini terungkap ketika ia mencoba nego dengan Dokter Sholeh untuk membantunya dalam usaha bersaing.

Namun, dari semua karakter negatif yang dimiliki Abdul Ghani, dia adalah orang yang gigih dan pekerja keras. Hal ini terlihat dari usaha dia yang mati-matian bekerja demi memperbaiki kehidupannya hingga akhirnya sukses.

“...Saya mulai berjuang mati-matian. Saya berhemat. Saya hampir tidak pernah beli apa-apa. Setiap detik saya harus menghasilkan uang." ( $(\mathrm{llm}, 362)$. "Saya tidak menyerah dengan keadaan. Saya bangkit. Kerugian itu harus saya tebus dalam waktu yang singkat. Saya mencari jalan pintas....." (hlm, 362).

Tabel 1. Tingkat Kepribadian Tokoh-tokoh Utama

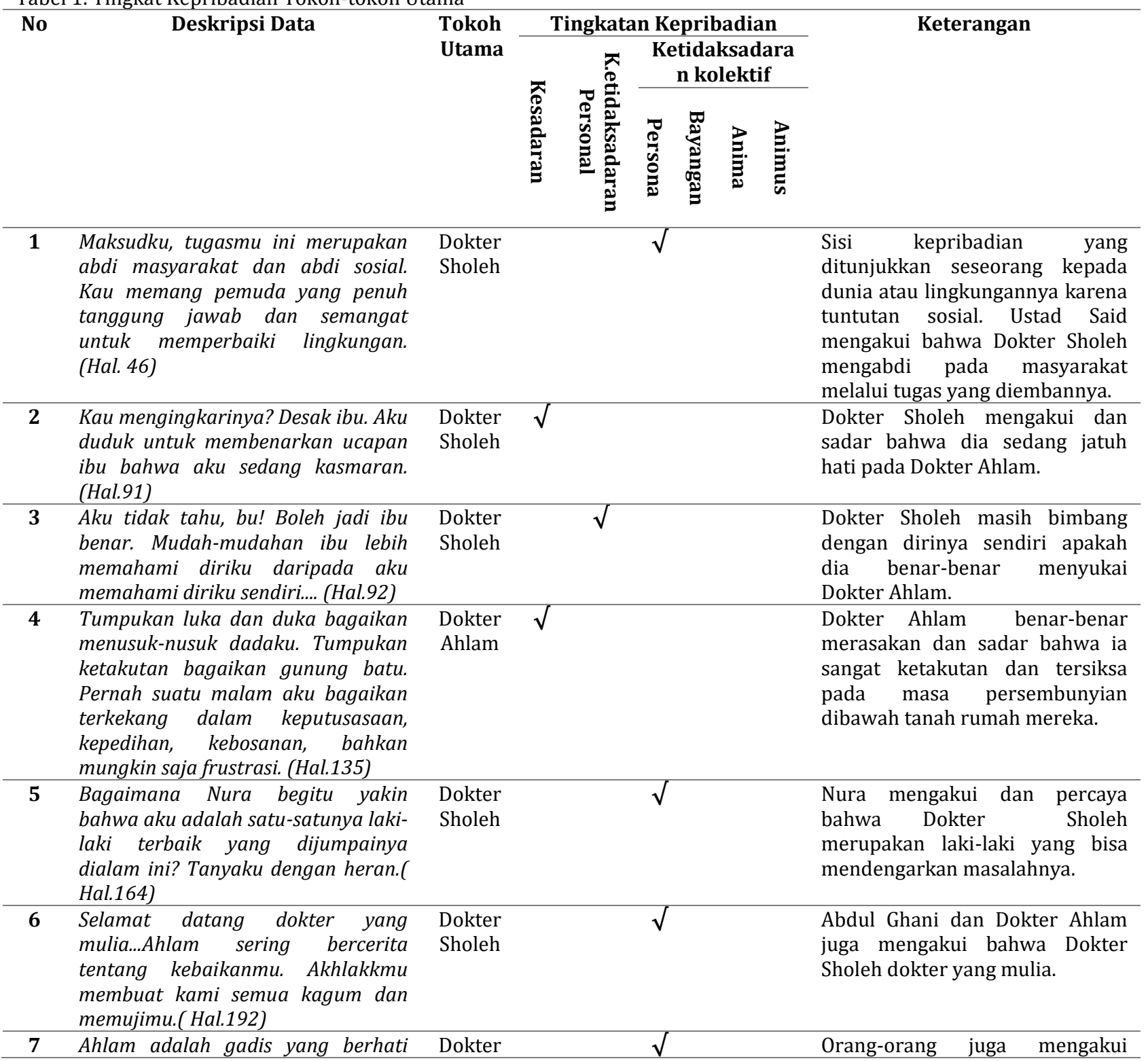




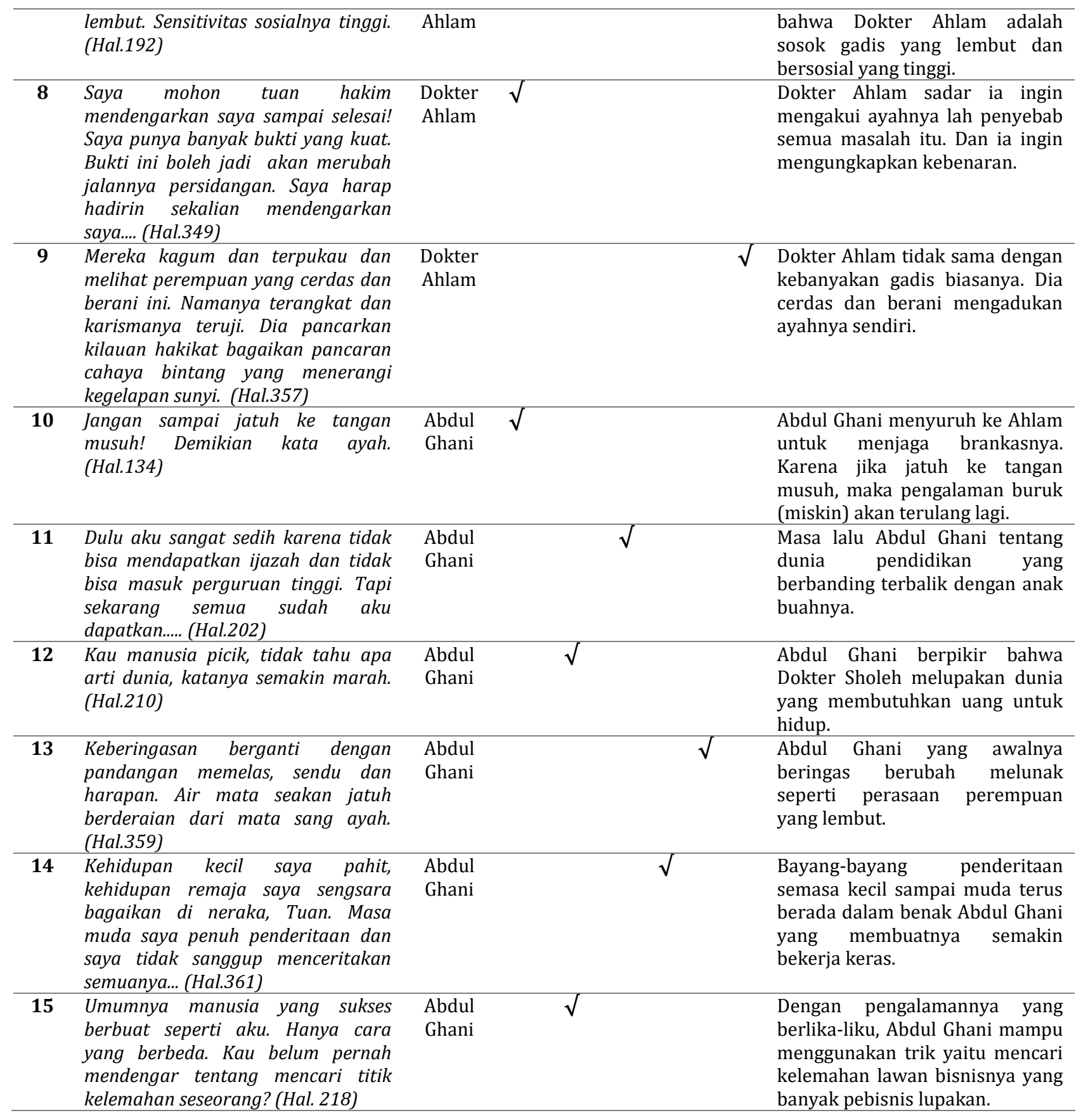

Tabel 2. Tipe Kepribadian Tokoh-tokoh Utama

\begin{tabular}{|c|c|c|c|c|c|c|c|c|c|c|}
\hline \multirow[t]{3}{*}{ No } & \multirow[t]{3}{*}{ Deskripsi Data } & \multirow{3}{*}{$\begin{array}{l}\text { Tokoh } \\
\text { Utama }\end{array}$} & \multicolumn{7}{|c|}{ Tipe kepribadian } & \multirow[t]{3}{*}{ Keterangan } \\
\hline & & & \multicolumn{4}{|c|}{ Ekstraversi } & \multicolumn{3}{|c|}{ Intraversi } & \\
\hline & & & $\stackrel{0}{3}$ & कृ & : & 鸹 & 总 & : & 离 & \\
\hline 1 & $\begin{array}{l}\text { Kau keras kepala seperti } \\
\text { Munatabi. Suatu hari kau } \\
\text { pasti dibunuh orang dengan } \\
\text { memenggal lehermu. (Hal. 32) }\end{array}$ & $\begin{array}{l}\text { Dokter } \\
\text { Sholeh }\end{array}$ & & & & & $\sqrt{ }$ & & & $\begin{array}{l}\text { Dokter Sholeh memiliki sifat } \\
\text { keras kepala. }\end{array}$ \\
\hline 2 & $\begin{array}{l}\text { Menurutmu, apa sebabnya } \\
\text { bayi itu dibuang oleh ibunya, } \\
\text { Hanin? (Hal. 40) }\end{array}$ & $\begin{array}{l}\text { Dokter } \\
\text { Sholeh }\end{array}$ & & & & $\sqrt{ }$ & & & & $\begin{array}{l}\text { Rasa ingin tahu Dokter Sholeh } \\
\text { sangat tinggi dan ia mencari tahu } \\
\text { sesuatu yang baru. }\end{array}$ \\
\hline 3 & Oh Paman Darwis, hidupnya & Dokter & $\sqrt{ }$ & & & & & & & memikirkan \\
\hline
\end{tabular}




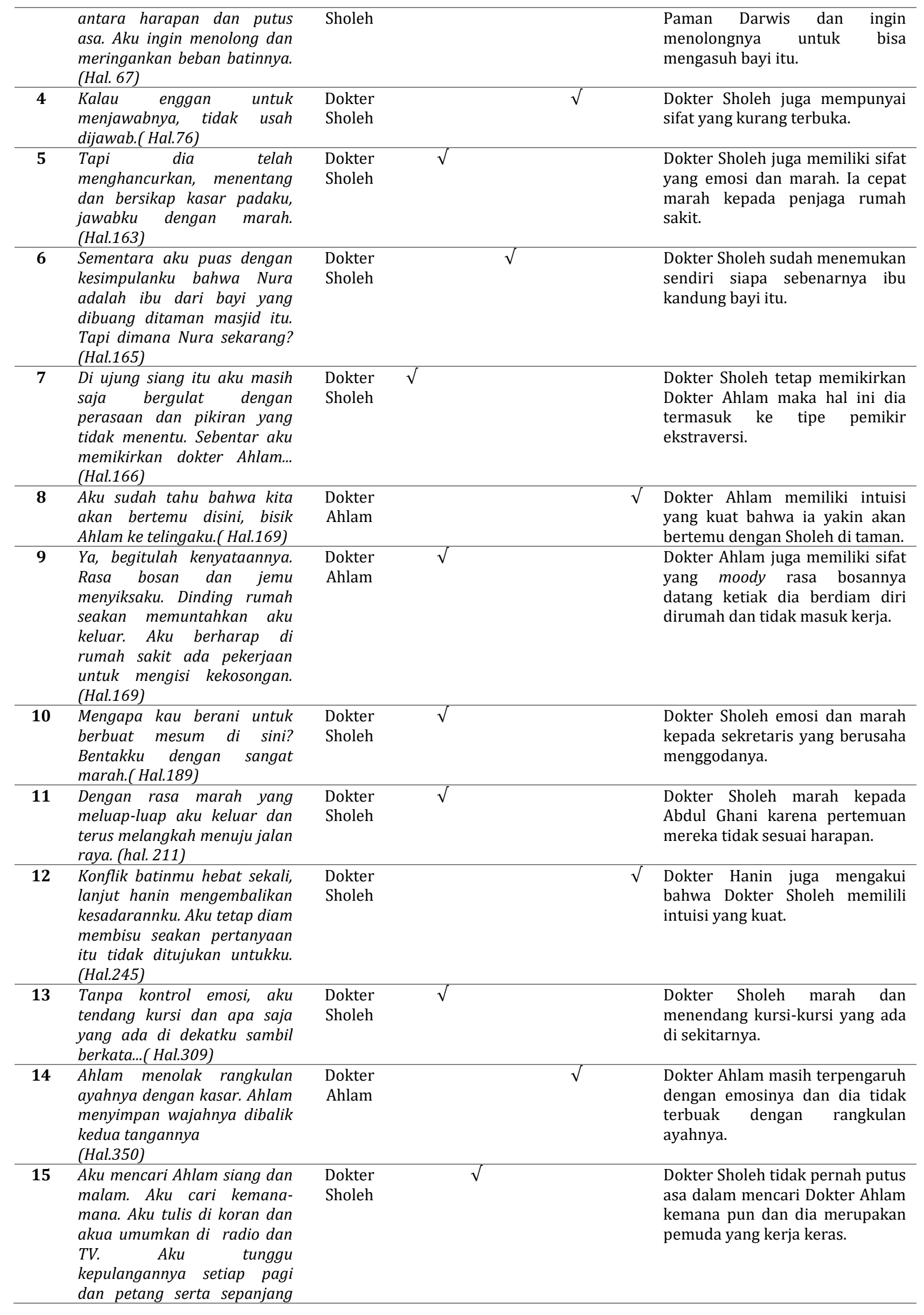




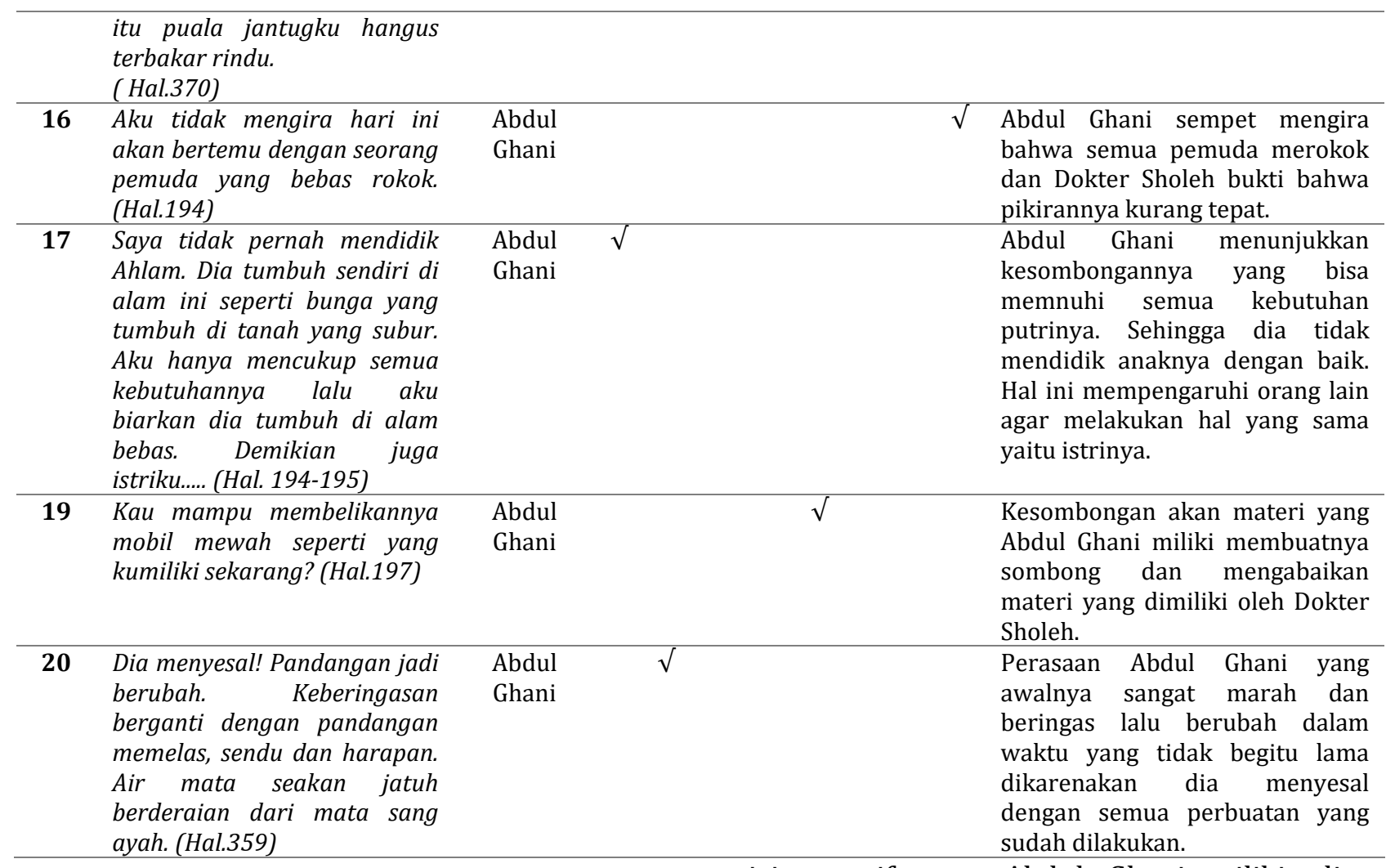

\section{KESIMPULAN}

Berdasarkan rumusan masalah, terdapat beberapa kesimpulan yang didapat peneliti sesuai dengan hasil temuan. Pertama, deskripsi tokoh-tokoh utama: Dokter Sholeh, Dokter Ahlam dan Abdul Ghani Zahabi dalam novel Mencari Perempuan yang Hilang karya DR. Imad Zaki, alih bahasa oleh Dr. Zuriyati. Dokter Sholeh mempunyai karakter yang positif seperti baik, peduli dengan permasalahan di masyarakat, penyayang terlihat dari rasa simpati pada bayi malang, amanah dengan semua cerita rahasia Dokter Ahlam padanya, tulus dan setia yang terlihat pada pengorbanannya menunggu kehadiran Dokter Ahlam sang pujaan hati yang telah mencuri cintanya, dan sangat menjunjung tinggi nilai kebenaran dalam kehidupannya. Dokter Ahlam mempunyai karakter yang positif walaupun pada masa kecilnya dia tidak mendapatkan kasih sayang yang sama dengan apa yang Dokter Sholeh dapatkan di keluarganya. Dokter Ahlam seorang wanita yang cerdas, lembut, simpati, penyayang, amanah, tulus dan berani. Dan Abdul Ghani Zahabi mempunyai karakter kejam. Hal ini terlihat dari beberapa pengakuan tentang dirinya di pengadilan yang menyatakan bahwa dia adalah penjahat, pencuri, peminum, pembunuh, dan penipu. Namun, dibalik semua sisi negatif yang Abdul Ghani miliki, dia mempunyai jiwa juang yang sangat tinggi. Dia bekerja sangat keras agar status sosialnya berubah. Jadi, apa yang dia miliki adalah hasil dari usaha kerasnya sejak kecil hingga sekarang.

Rumusan masalah kedua adalah tingkatan kepribadian berdasarkan teori Jung yang terdapat pada tokoh-tokoh utama: Dokter Sholeh, Dokter Ahlam dan Abdul Ghani Zahabi dalam novel Mencari Perempuan yang Hilang karya DR. Imad Zaki, alih bahasa oleh Dr. Zuriyati. Dokter Sholeh cenderung memiliki tingkatan kepribadian kesadaran dan ketidaksadaran kolektif (persona)karena terlihat dari sikap Dokter Sholeh yang mengabdi pada masyarakat melalui tugas yang diembannya dan diakui oleh Ustad Said bahwa ia adalah pemuda yang penuh tanggung jawab dan semangat untuk memperbaiki lingkungan. Dokter Ahlam cenderung memiliki tingkatan kepribadian kesadaran dan ketidaksadaran kolektif (animus) karena terlihat dari sikap Dokter Ahlam yang berbeda dengan wanita pada umumnya yaitu berani mengadukan ayahnya sendiri ke pengadilan. Dan Abdul Ghani Zahabi cenderung memiliki tingkatan kepribadian ketidaksadaran personal dan ketidaksadaran kolektif (persona, bayangan, dan anima) 
karena terlihat dari masa lalunya tentang dunia pendidikan yang semuanya bisa dibayar dengan uang, bayang-bayang penderitaan masa kecilnya membuat ia bekerja semakin keras, dan pengalaman lika-likunya membuat ia mengetahui cara melemahkan lawan bisnisnya.

Rumusan masalah yang ketiga adalah tipe kepribadian berdasarkan teori Jung yang terdapat pada tokoh-tokoh utama: Dokter Sholeh, Dokter Ahlam dan Abdul Ghani Zahabi dalam novel Mencari Perempuan yang Hilang karya DR. Imad Zaki, alih bahasa oleh Dr. Zuriyati. Dokter Sholeh cenderung termasuk kedalam tipe kepribadian ekstroversi (pemikir, perasa dan intuitif). Dokter Sholeh termasuk tipe kepribadian ekstroversi dilihat dari sikap terbuka kepada orang tuanya seperti menceritakan apa yang dia alami kepada orang tuanya, mudah bersosialisasi dengan orang lain, sifat perasanya terlihat dari sikap Dokter Sholeh terdahap kasus Nura yang dizalimi, dan Dokter Sholeh berusaha untuk mengungkapkan pelaku yang menzaliminya. Dokter Ahlam cenderung termasuk kedalam tipe kepribadian introversi (perasa dan intuitif) karena menutup diri dan enggan berbagi keresahan dengan orang lain yang menyebabkan terjadi kesalahpahaman dengan Dokter Sholeh. Dan Abdul Ghani Zahabi cenderung termasuk kedalam tipe kepribadian ekstroversi (pemikir dan perasa) dan introversi (pemikir dan intuitif) karena terlihat dari sikapnya yang selalu menekandan ingin menguasai orang lain serta semua hal harus sesuai dengan keinginannya.

\section{DAFTAR PUSTAKA}

Feist, Jess dan Gregorry J. Feist. (2006).Theories of Personality. New York: McGraw-Hill.

Firdaus, Pilda Nugraha. (2016). Gangguan Kepribadian Tokoh dalam Novel Mencari Perempuan yang Hilang Karya Dr. Imam Zaki: Kajian Psikologi Sastra. Diakses pada https://surauwongkulon.blogspot.co.id/2017/02/gangguan-kepribadian-tokoh-dalamnovel.html (tanggal 26 Oktober 2017).

Howard, S Friedman dan Miriam, W Schustack. (2008). Kepribadian Teori Klasik dan Riset Modern. Jakarta: Erlangga.

Jaenudin, Ujam. (2012). Psikologi Kepribadian. Bandung: CV Pustaka Setia.

Matthew, H Olson. (2013). Pengantar Teori-teori Kepribadian. Yogyakarta: Pustaka Pelajar.

Pangtoro, Pratiwi Nadya. (2014). Kepribadian Tokoh Utama dalam Novek Madogiwa no Totto Chan Karya Tetsuko Kuroyanagi berdasarkan Tinjauan Psikoanalisis Carl Gustav Jung. Jakarta: Pascasarjana UNJ.

Schultz, D., \& Schultz, S. (2005). Theories of Personality, (8th ed). Belmont, CA: Thomson Wadsworth. 